\title{
Analysis of the Health Expenditure's Weight in the Household Economy in Kourtheye (Niger)
}

\author{
Sanouna Abdoulkarimou ${ }^{1}$, Soumana Boubacar ${ }^{1}$, \\ Idrissa Saidou Mahamadou ${ }^{1}$, Adam Toudou', \\ Moumouni Hassane ${ }^{3}$
}

\author{
${ }^{1}$ Department of Sociology and Rural Economics, Faculty of Agronomics sciences, Abdou Moumouni University of \\ Niamey, BP 10960 Niamey, Niger \\ ${ }^{2}$ Department of vegetable Production, Faculty of Agronomics sciences, Abdou Moumouni University of Niamey, \\ BP 10960 Niamey, Niger \\ ${ }^{3}$ Faculty of Health Sciences, Abdou Moumouni University of Niamey, BP 237 Niamey-Niger
}

\begin{abstract}
Farm households in Niger face health expenses each year. This study on Analysis of the health expenditure's weight in the household economy was conducted in the rural commune of Kourtheye, in the department of Tillaberi located in the Tillaberi region (NIGER). The adopted methodology is based on a documentary research and a collection of primary data at the level of the households in 6 villages. The extensive Household economic approach (HEA) methodological approach, combined with the amplitude class discretization method was used. A total of 125 farm households were surveyed. the study shown that the share of health spending by farm households increases from very poor households to wealthy households. In relative value among the very poor (VP), the share of health expenditure is $13.4 \%$ against $15.4 \%$ among the poor $(\mathrm{P}), 19.2 \%$ among the middle (M) and $21 \%$ among the wealthy (W). Thus, according to the World Health Organization, these households incur catastrophic expenses. The main pathologies in the area are chronic diseases, malaria, bilharzia and work accidents. Spending by households on self-medication is higher among VP (63\%) and P (57\%), and low among the middle $(15 \%)$ and wealthy $(19 \%)$. This is explained by the fact that the poor do not have enough financial resources to care for their sick in health centers, unlike the middle and wealthy farm households.
\end{abstract}

Keywords: Household, Share of Expenditure, Health, Household Economy

\section{Introduction}

Health is an important component of the household's standard of living and is therefore one of the major concerns of public authorities (INS, 2011). The composition of household spending, measured by the share of spending in the budget for consumption needs, is an indicator of living standards. This is a reality, whether it is a matter of basic needs (e.g. food, shelter, transport, clothing) or any other need that can be satisfied by the market consumption of goods and services (e.g. leisure). (Stéphane Crespo1 2018). Spending on health has steadily increased in OECD countries (Jos Schoonbroodt, 1997). They include health services (preventive and curative), family planning activities, activities relating to nutrition and emergency aid reserved for health. However, they exclude the provision of water and sanitation services. The share of total health expenditure in global gross domestic product (GDP) increased from $3 \%$ in 1948 to more than $8 \%$ in 2004.In 2016, it is estimated that health spending averaged $9.0 \%$ of GDP in OECD countries, (OECD, 2017). In 2018, consumption of healthcare and medical goods (CSBM) is provisionally estimated at 203.5 billion euros. It progressed more slowly in 2018 than in $2017(+1.5 \%$ after $+1.7 \%)$, due to the marked slowdown in hospital care (DREES, 2019). The inequality of access to public health expenditure is particularly high in Africa, compared to other developing regions (Davoodi et al. 2003). Niger, in particular, achieved $7.2 \%$ of GDP in current expenditure on health in 2015 (WHO, 2018).There is, at the microeconomic level as at the macroeconomic level, a poverty trap associated with health: a family struck by the illness of one of its members can find itself permanently impoverished due to the loss of income associated with the illness and the cost of access to the care (Jean-Claude Berthélemy and Juliette Seban, 2009).In addition, at the microeconomic level, catastrophic proportions of health expenditure are observed, thus reflecting the level of poverty and vulnerability of households.

This article is published under the terms of the Creative Commons Attribution License 4.0 Author(s) retain the copyright of this article. Publication rights with Alkhaer Publications. Published at: http://www.ijsciences.com/pub/issue/2020-01/

DOI: 10.18483/ijSci.2256; Online ISSN: 2305-3925; Print ISSN: 2410-4477 
Nigerien households, especially those living in rural areas and those in the river valley in particular face a much more critical situation. The Tillabéry region is one of the regions where the majority of its households live and carry out activities in the Niger river valley. Many households face a recurring health problem, which forces them to make often some catastrophic expenditure.

This is why, this study focuses on an analysis of analysis of the health expenditure's weight in the household economy of the municipality of Kourthey in the department of Tillabéry. Thus, the overall objective of this study aims to contribute to the understanding of the importance of health expenditure for agricultural households in the commune of Kourthey in the department of Tillabery. More specifically it is about to:

* Evaluate the weight of health expenditure according to the socioeconomic characteristics of households

* Estimate health costs by morbidity according to socioeconomic categories of households

* Appreciate the types of health expenditure by socio-economic category

\section{Materials and Methods of Analysis}

The main materials used in this study are:

ARCGIS 10.3 software, for making and producing the thematic map; EXECEL 2016, SPSS 20, for statistical data processing; A survey sheet for data collection and an interview sheet for the focus group. The latter was carried out in each village, and made it possible to identify the agricultural households concerned. The methods and approaches used in this study refer to those of Denis R, (2002), Jean-Claude B and Juliette S (2009), Soumana B et al, (2016), and Brigitte D H, (2017). Indeed, Denis R, (2002) and Brigitte D, H, 2017 in their respective studies on the individual determinants of health expenditure and Aging of the population and growth in health expenditure, adopted a descriptive analysis, as well as a modelization. This method of analysis, adopted in this study, allowed to know the shares of household health expenditure and to make an estimation of this expenditure in the overall household budget. The main variables considered for this study are the level of health expenditure and the socioeconomic characteristics of households (Jean-Claude B and Juliette S, 2009). In order to complete the analysis on the effects of health care spending, two variables designed to capture other factors that can influence access to the care are introduced. It is about the individual wealth of households, and their level of education.The first variable is defined as the wealth aggregate and the second is associated with the education of mothers, who may reasonably be expected to play an essential role in child health. First, each of these variables of access to health services by quintile is linked to, on the one hand, total health expenditure per person, and on the other hand, the wealth and education variables mothers by quintile. The second variable was taken into account in the qualitative characteristic of households. The following ratings and formulas are used in the calculation of the various expenses:

For food, the monthly expenditure is given by the following formula:

$\mathrm{N}=\sum N \mathrm{ix} 30$. Ni: daily expenditure of household $\mathrm{i}$ for food; Di: monthly household expenditure $\mathrm{i}$ for other items. This result is then multiplied by 12 for annual expenditure. Other expenses outside of health are given by the following equation:

$\mathrm{Dp}=\mathrm{Y}$ Dpi/m where Dpi denotes the expenditure made by household $\mathrm{i}$ for item $\mathrm{p}$, and $\mathrm{m}$ denotes the total number of households considered in the study. Health expenditure by households is calculated per individual and then per household using the following formula. $\mathrm{C}=\sum \mathrm{xi} / \mathrm{n}$ where $\mathrm{C}$ denotes the average monthly cost per individual, $x$ represents the costs of treatment by disease and $n$ corresponds to the total number of diseases in the area. With regard to the method allowing socio-economic categorization of agricultural households, the following procedure is adopted:

A first step is to perform classes of the same extent. For this, the following approach has been adopted as illustrated by the following diagram (Didier P., 2007 ): 


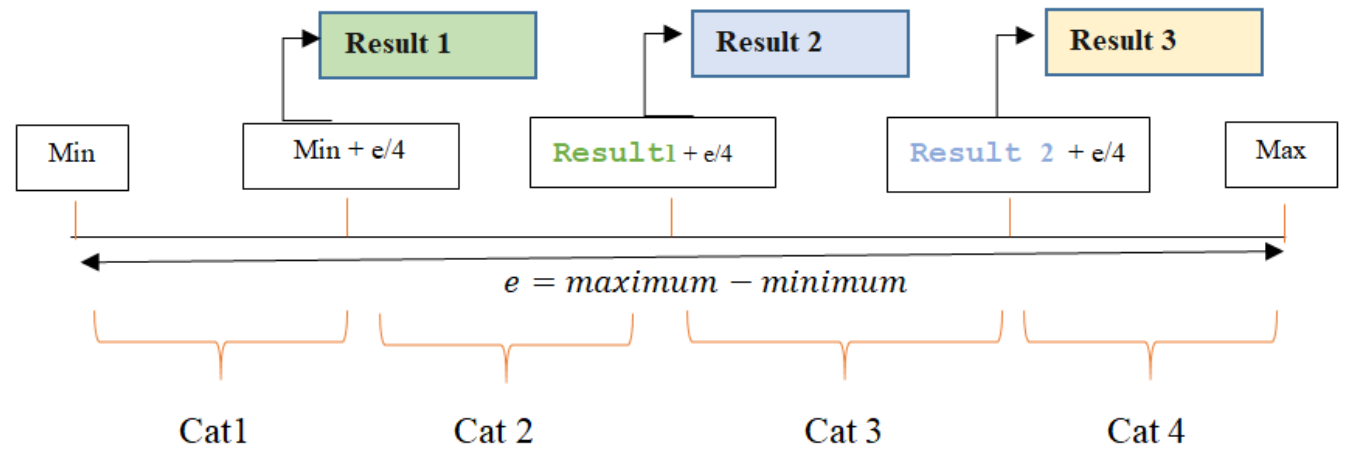

The second step of this method consists in determining the components of well-being and their indicators (Soumana B et al, 2016). The indicators were assessed on a scale changeable from 1 to 4 .

Initially, the values of all the indicators were harmonized across a scale of 1-4. The well-being classes are calculated from the measures of the components. The components taken into account are the economy, health, food, investment in agriculture.

The second step is a score calculation for each component of well-being

The score for each component of well-being (CWB) $=\Sigma \mathrm{Ni} / \mathrm{ni}$, with $\mathrm{Ni}=$ score of the indicator obtained and $\mathrm{ni}=$ number of indicators in each component.

Third, the overall well-being score is determined.

The global well-being score $(\mathrm{GWB})=\Sigma(\mathrm{CWB}) / \mathrm{ns}$, with CWB the score of the component of well-being, and $n s$ the number of component of well-being.

At the end of the procedure, categories are established.

All the households which obtained the value $(<=1)$ of the scale, were considered as VP(Very poor); [2-3 [like the Poor (P); [3-4 [ as Medium (M); and $(>=4)$ as wealth $(\mathrm{W})$.
Type of study, target population, inclusion and exclusion criteria

It is a transversal study. The Study Population is made up of heads of farming households located in the villages of the river valley in the department of Tillabéry. The study concerned heads of households located in villages in the farming area.

\section{Presentation of the study area}

Located in the far west of Niger, the Tillabéri region is the youngest of the eight regions of the country due to its creation, which took place by Ordinance No. 8888-20 of April 7, 1988. It is limited to the northwest by the region of Tahoua, in the East by the Dosso region, in the West by Burkina Faso and in the South by Benin. The Tillabéri Region is subdivided into six (6) departments Filingué, Kollo, Say, Ouallam, Téra, Tillabéri(Fig. 1). It covers an area of $92,908 \mathrm{~km}^{2}$. The study was carried out in the commune of Kourtheye, particularly in its riparian part composed essentially of villages along the river, those of the flood plain and those of the alluvial terraces. 


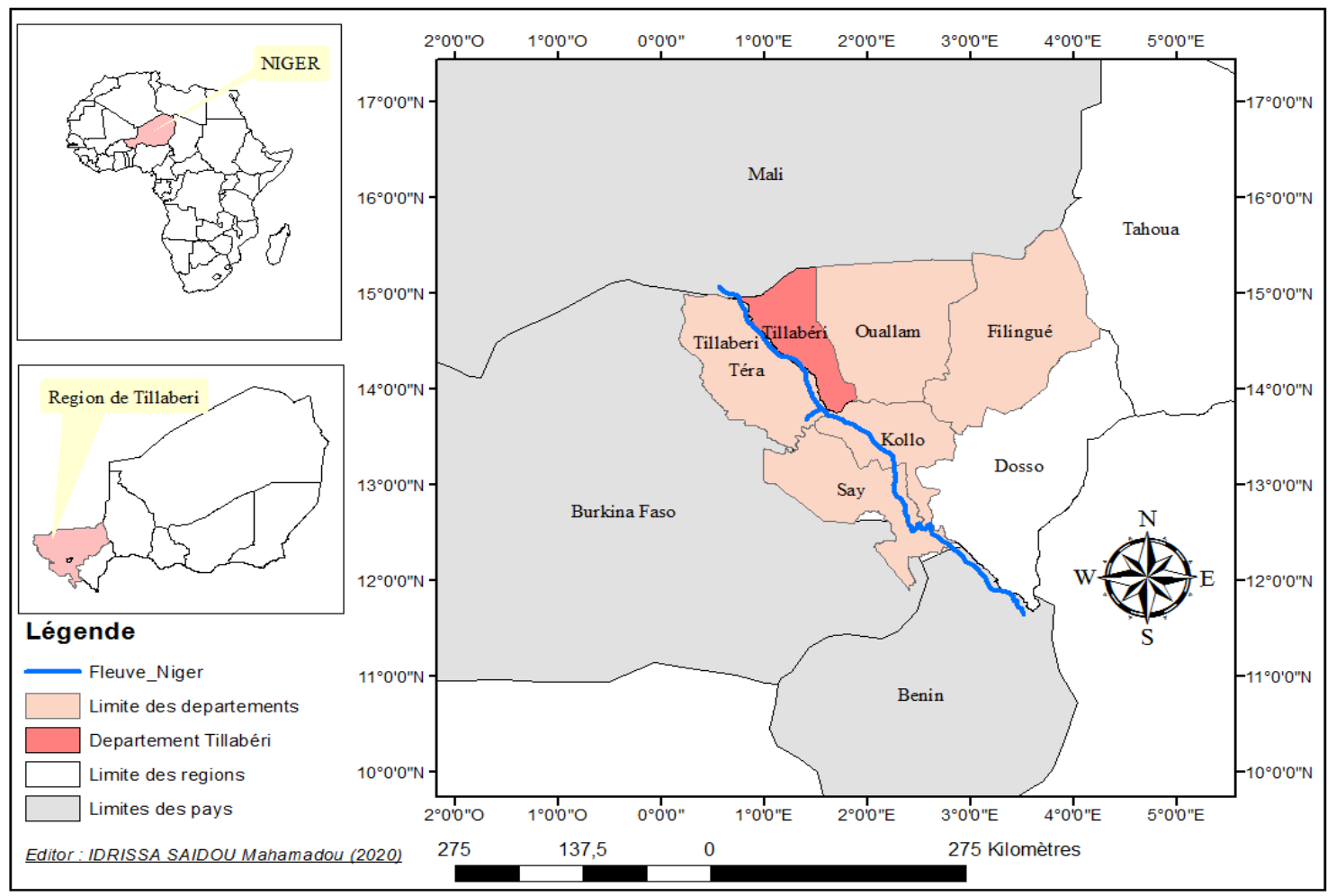

Fig. 1: location of the study area

\section{Results}

\section{Socio-economic characteristics of respondents}

The analysis shows that there is a slight variation in the average age (around 50) of heads of very poor households as well as the middle. The flattening coefficient shows a normal population age distribution (0.04). With regard to the land factor, represented here, by the area (in ha) of dry and irrigated crops (IC), the variation is gradual and significant $(\mathrm{k}=24.3)$ within the Socio-economic categories (SEC); going from 0.22 ha for the very poor (VP) to 2.8 ha for the wealthy (W) for irrigated crops. The middle classes (M) exploit an average area of 2.20 ha. However, the area of dry crops (DC) exploited, goes from 0.78 ha in VP to 2.5 ha in W. The average annual income also differs by category from 419058 Fcfa in VP, 604333 Fcfa in P, 1021 $207 \mathrm{Fcfa}$ in $\mathrm{M}$ to $2100250 \mathrm{Fcfa}$ in $\mathrm{W}$. the average annual income of the entire statistical population is estimated at 1036212 FCFA. This information is recorded in table $\mathrm{n}^{\circ} 1$

Table 1: Quantitative characteristics of the respondents

\begin{tabular}{llllllllll}
\hline Quantitative variables & \multicolumn{7}{l}{ Socioeconomic categories } & \multicolumn{7}{l}{ Statistical variables } \\
\cline { 2 - 11 } & $\mathrm{VP}$ & $\mathrm{P}$ & $\mathrm{M}$ & $\mathrm{W}$ & Min & Max & Mean & Std.de & Kurtosi \\
\hline Age of household heads & 55,1 & 50,9 & 49,8 & 46,5 & 24,0 & 96,0 & 51,6 & 15,4 & $\mathbf{, 0 4 7}$ \\
\hline Household size & 6,5 & 7,6 & 11,7 & 16,6 & 2,0 & 32,0 & 9,9 & 5,5 & $\mathbf{2 , 1}$ \\
\hline Agricultural assets & 4 & 4,7 & 6,6 & 12,1 & 1,0 & 22,0 & 5,6 & 4,1 & $\mathbf{2 , 0}$ \\
\hline $\begin{array}{l}\text { Average cultivated } \\
\text { (IC in ha) }\end{array}$ & 0,22 & 0,35 & 1,94 & 2,85 &, 12 & 5,0 &, 8 & 1,04 & $\mathbf{2 4 , 9}$ \\
\hline $\begin{array}{l}\text { Average cultivated } \\
\text { DC (ha) }\end{array}$ & 0,78 & 1,0 & 2,20 & 2,75 &, 24 & 5,2 & 1,9 & 1,09 & $\mathbf{- , 1 4}$ \\
\hline $\begin{array}{l}\text { Average annual household } \\
\text { income (FCFA) }\end{array}$ & 41905 & 604333 & 1021207 & 2049583 & 375000 & 3121457 & 1036212 & 5,51 & $\mathbf{1 5 , 1 9}$ \\
\hline
\end{tabular}

Furthermore, it emerges from this analysis that in terms of farming, the Middle households are the majority. It should be noted that a small proportion of women in the workforce. The main activity is agriculture in all socio-economic categories. Most of the respondents have a low level of education (table 2) 
Table 2: Qualitative characteristics of the respondents

\begin{tabular}{|c|c|c|c|c|c|}
\hline \multicolumn{6}{|c|}{ Qualitative variables } \\
\hline \multirow[t]{2}{*}{ Variables } & \multirow[t]{2}{*}{ Modalities } & \multicolumn{4}{|c|}{ Socioeconomic categories } \\
\hline & & VP & $\mathrm{P}$ & $\mathrm{M}$ & $\mathrm{W}$ \\
\hline \multirow[t]{2}{*}{ Gender } & Male & $16 \%$ & $22 \%$ & $43 \%$ & $11 \%$ \\
\hline & female & $5 \%$ & $3 \%$ & $0 \%$ & $0 \%$ \\
\hline \multirow{4}{*}{ Secondary activity } & Trade & $7 \%$ & $2 \%$ & $15 \%$ & $10 \%$ \\
\hline & fishing & $10 \%$ & $24 \%$ & $0 \%$ & $0 \%$ \\
\hline & Daily work & $17 \%$ & $10 \%$ & $0 \%$ & $0 \%$ \\
\hline & Other & $0 \%$ & $2 \%$ & $2 \%$ & $0 \%$ \\
\hline \multirow{5}{*}{ Educational level } & Unschooled & $12 \%$ & $10 \%$ & $9 \%$ & $4 \%$ \\
\hline & Primary leve & $5 \%$ & $7 \%$ & $12 \%$ & $2 \%$ \\
\hline & Secondary level & $3 \%$ & $2 \%$ & $7 \%$ & $3 \%$ \\
\hline & higher level & $0 \%$ & $0 \%$ & $2 \%$ & $3 \%$ \\
\hline & Quranic study & $10 \%$ & $5 \%$ & $3 \%$ & $2 \%$ \\
\hline \multirow{3}{*}{ Marital status } & Married & $16 \%$ & $23 \%$ & $43 \%$ & $11 \%$ \\
\hline & Divorced & $1 \%$ & $0 \%$ & $0 \%$ & $0 \%$ \\
\hline & Widower & $4 \%$ & $3 \%$ & $0 \%$ & $0 \%$ \\
\hline
\end{tabular}

Weight of health expenditure according to socioeconomic characteristics of households

It should be noted that all expenses increase from VP to $\mathrm{W}$. The most important item of expenditure among the $\mathrm{W}$ is constituted by investments in irrigated
crops(IC). On the other hand, among the other socioeconomic groups, food occupies the first place in expenditure. Regarding the total average cost in health, we observe the same trend as illustrated by figure $\mathrm{n}^{\circ} 1$.

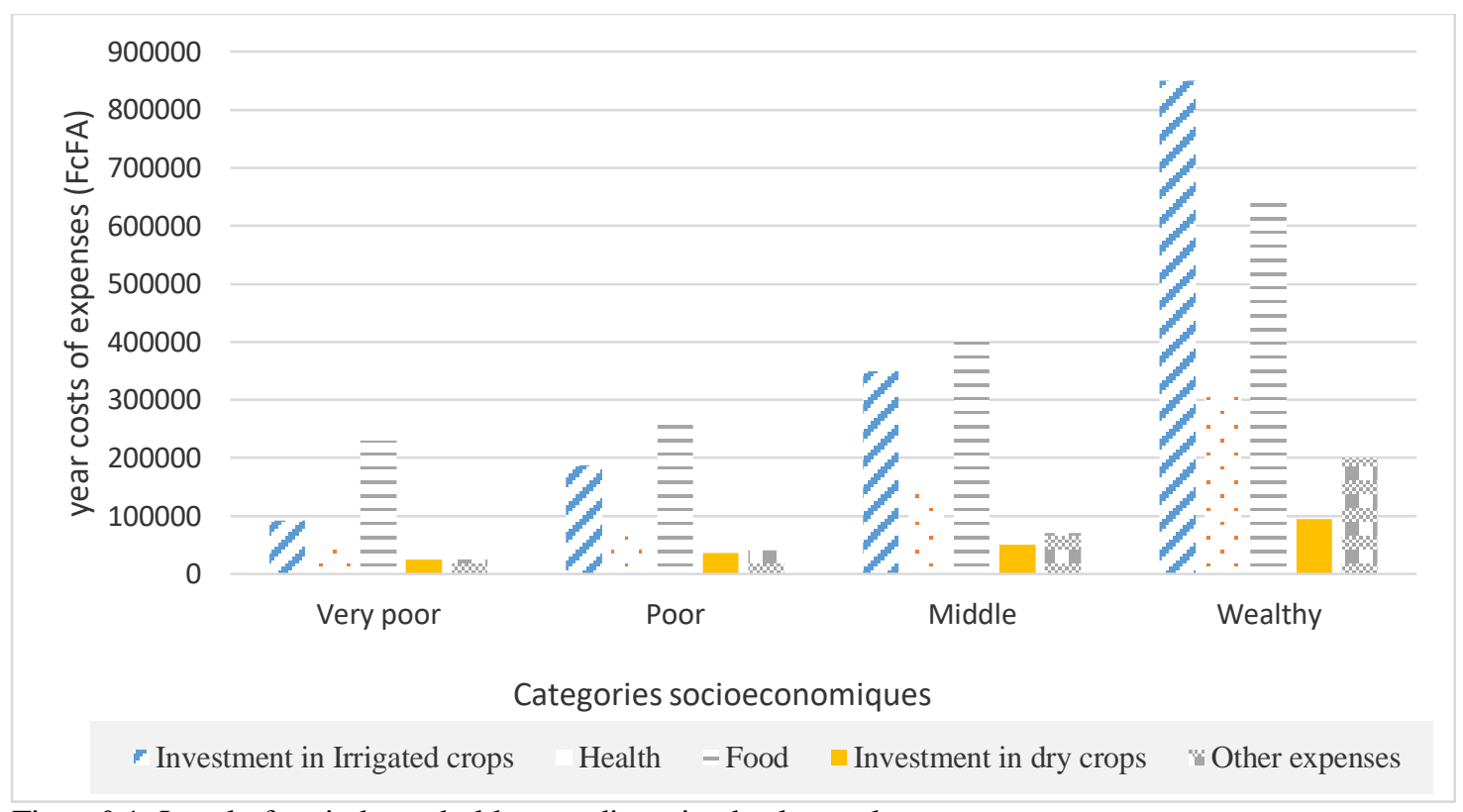

Fig. $\mathrm{n}^{\circ}$ 1: Level of main household expenditure in absolute value

These differences between socio-economic groups are much more noticeable when the results are presented in relative value (Figure 2). 


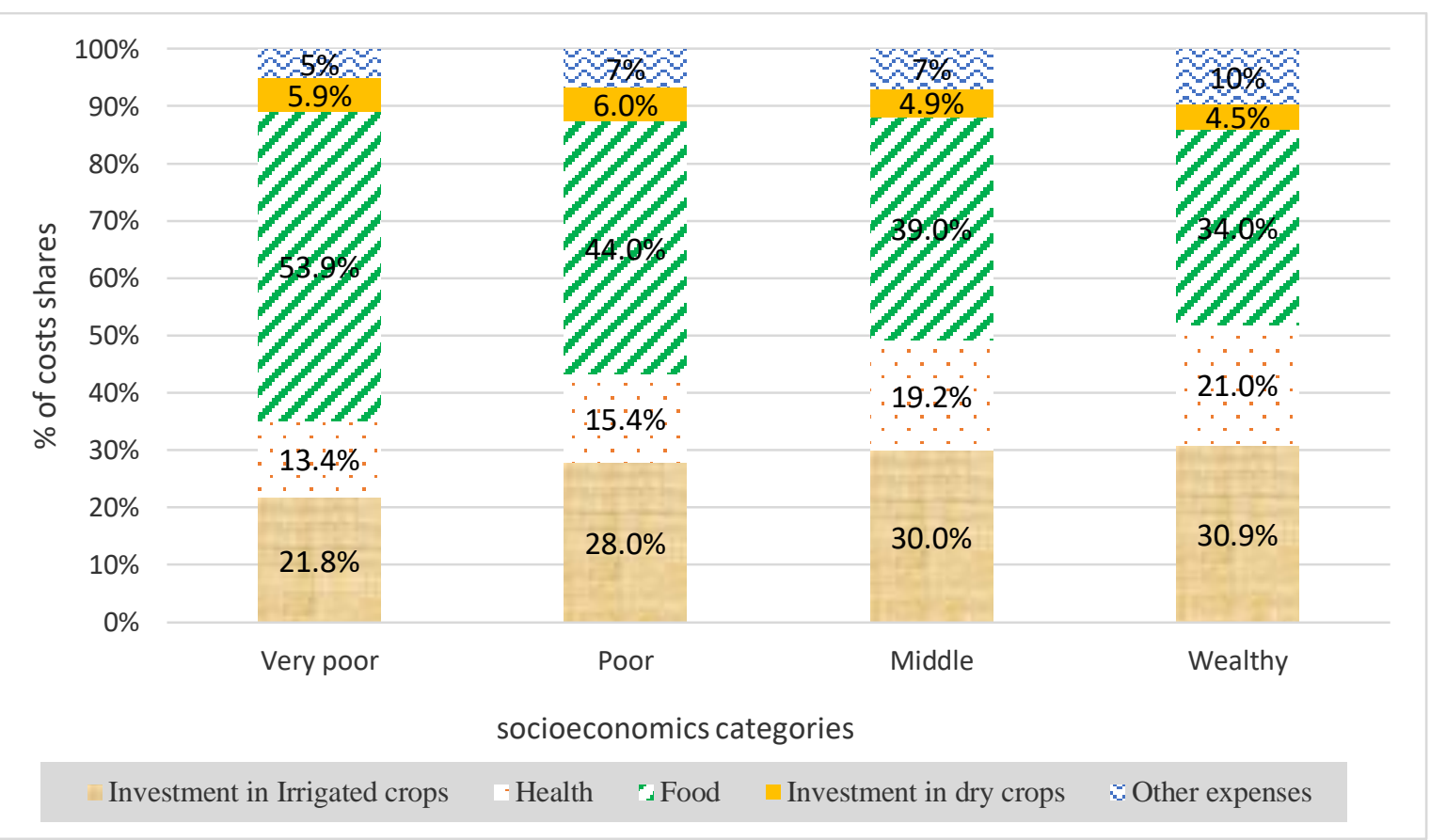

Fig. $\mathrm{n}^{\circ} 2$ : Level of main household expenditure in relative value

Assessment of levels of health expenditure according to international standards

The World Health Organization has set a critical threshold for health spending at a coefficient of 0.01 or $10 \%$ of total spending. Exceeding this threshold leads the household to a situation of catastrophic expenditure. Figure 3 illustrates this observation.

Share of expenditure

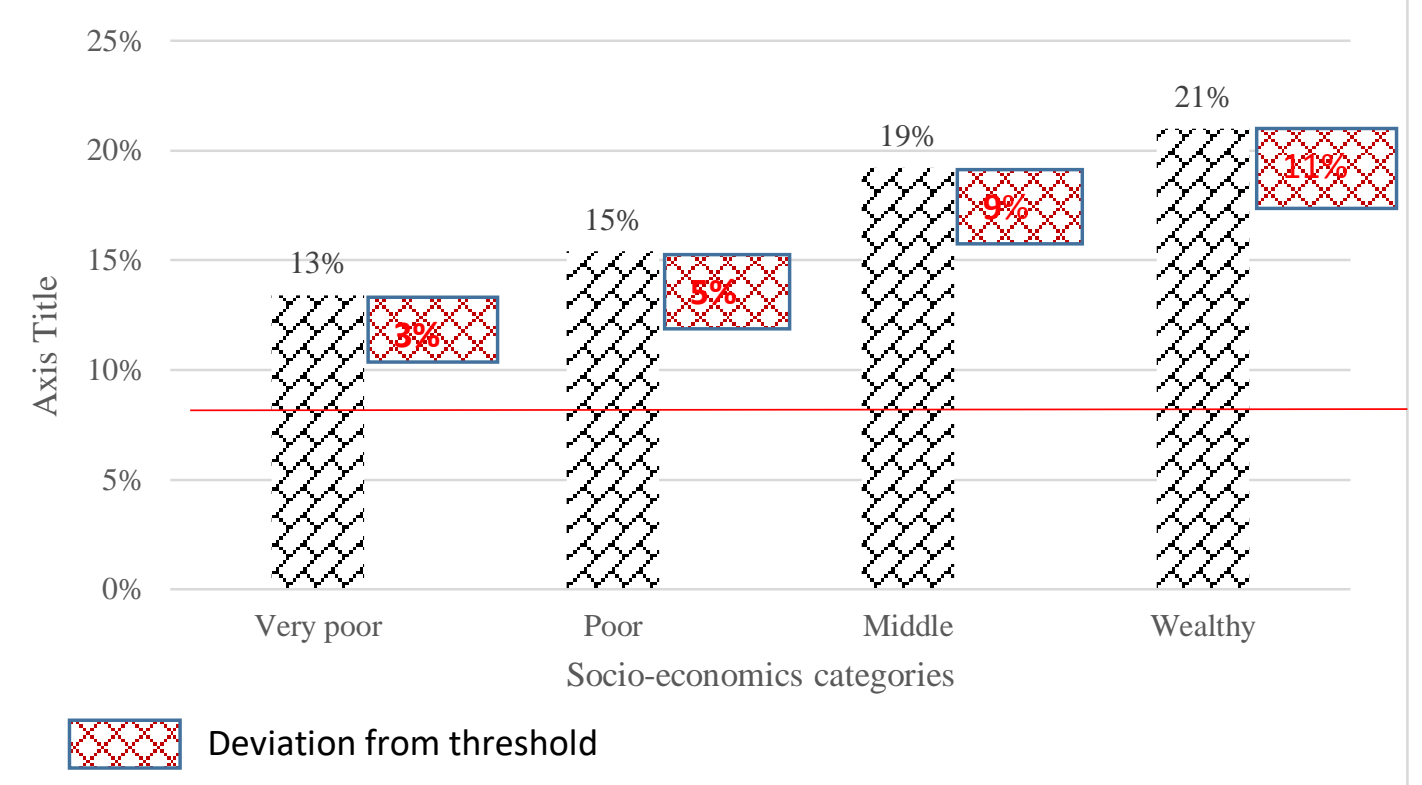

Fig. $\mathrm{n}^{\circ}$ 3: Assessment of health expenditure according to the WHO critical threshold

Distribution of health costs by morbidity according to socioeconomic categories of households

An analysis carried out on the distribution of the various expenses by morbidity and by socioeconomic categories shows that ophthalmological conditions, malaria, and chronic diseases are the main morbidities presenting high costs of care as shown in figure $n^{\circ} 4$. 


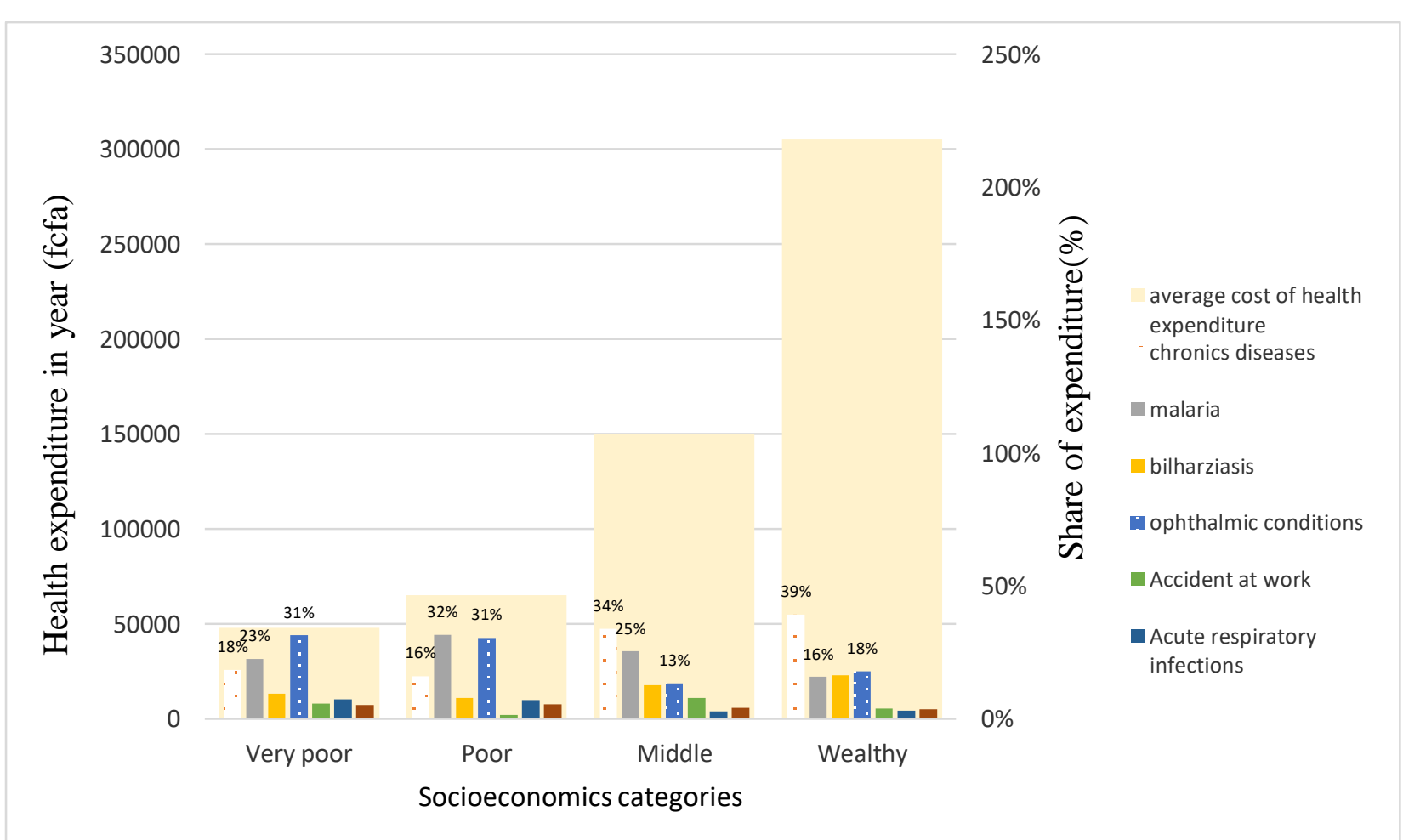

Fig. $\mathrm{n}^{\circ}$ 4: apportionment of expenses by morbidity in relative value

\section{Disaggregation of household health expenditure}

Furthermore, the results of the study show that if among the poor and very poor it is the expenditure made by auto-medication is greater, respectively in a ratio of $57 \%$ and $63 \%$, among the middle and wealthy. It is the direct costs in the health facilities which are respectively in a budgetary coefficient of $53 \%$ and $55 \%$ the highest as shown in figure $\mathrm{n}^{\circ} 5$.

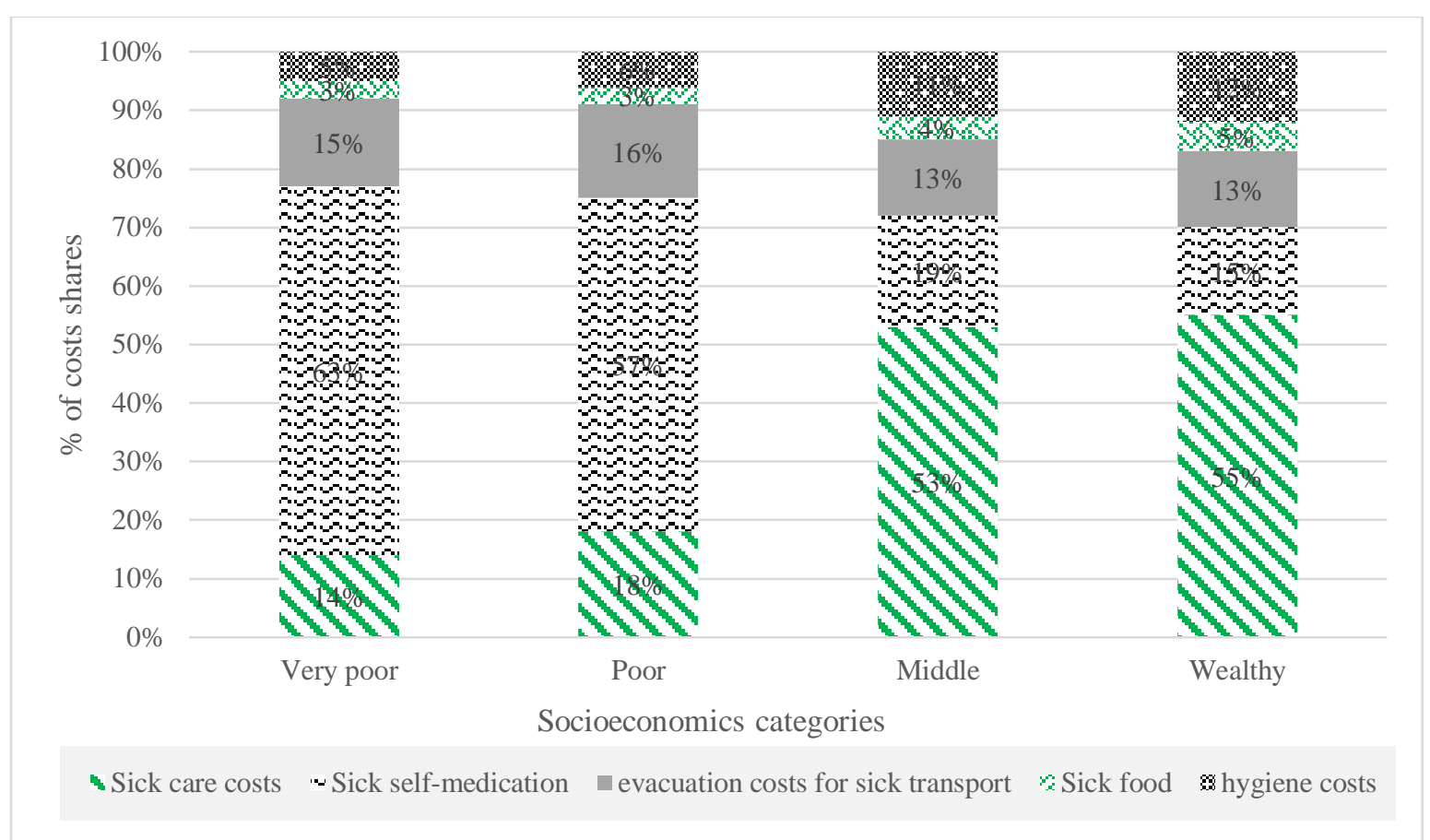

Fig. $\mathrm{n}^{\circ}$ 6: Components of health expenditure in relative value 


\section{Discussion}

Total spending on health occupies a huge share in the main household spending as demonstrated by CRESPO, Stéphane (2018). This share of health expenditure exceeds the critical threshold for all socioeconomic categories.

This increase may be due not only to the different costs of taking charge of the illnesses recorded in households (the degree of complication, treatment, prevention and other expenses linked to the indirect treatment process) but also to the total number of sick people whose the deleterious consequences heavily affect other expenses, such as food.Food, being an essential component for survival, it constitutes the main expenditure of households in the area, this corroborates with the results of the study carried out in Morocco (DHS, 1995) and confirmed as being the first WINTER G expenditure. (1967). The share of spending among the categories of middle and wealthy households is close to that obtained by Harouna T, (2012). To produce more, we will have to invest more in factors of production. This allows households to classify investments in agriculture as the second main expenditure. They also contribute to households in creating wealth, jobs and ensuring many functions, food production (Joseph G, and Martine, 2014 ). The weight of health expenditure according to socioeconomic characteristics represents the third main household expenditure as demonstrated by DHS in 1995. The rural environment constitutes one of the common characteristics of these two studies. On the other hand, in terms of relative share of health, the results are clearly superior to those obtained by the same author who reveals $6 \%$ as part devoted to health. Indeed, in this study, this share of health expenditure is catastrophic for all socio-economic categories.It is close to the health expenditure of Belgian households (Jos S, 1997), and that of the Harouna T study (2012) at MBODA, in Senegal, but is lower than that of average and wealthy agricultural households. The large shares of household health expenditure can be explained by the fact that the areas concerned by this study are characterized by several factors which favor the development of morbidities throughout the year.They can be climatic factors or geographic location of agricultural households in the area. The large share of expenditure on self-medication costs is found among the poor. This may be explained by the fact that the latter do not have enough financial resources to care for their patients in health centers. Self-medication practices based on the existence of a "family" medicine cabinet could also explain this phenomenon (Mireille E, 2002), while among the middle and better-off, it is the cost of care that represents a part significant expense. In terms of patient transport costs, the results are significantly higher than those obtained by Myriam M, Raphael T, and Alexis M in 2017 in France, where consumption of patient transport is $2.4 \%$.

\section{Conclusion}

According to the results, health represents the third main household expenditure after food and investments in agriculture. It is clear that the situation is precarious among agricultural households, who face catastrophic expenses in the care of their patients. This is not without consequences for other basic necessities. The main morbidities causing these catastrophic expenses are malaria, chronic diseases, bilharziasis and accidents at work in all socioeconomic categories. However, special emphasis must be placed on malaria, which is the first pathology that affects the physical capacity of farmers. The study reveals a significant weight in the shares of health expenditure, through self-medication among the categories of the very poor and poor. Furthermore, given the income available to the means and the wealthy; the share of expenditure for care costs is significant. To reduce catastrophic spending among farmers, actors need to be more involved in facilitating access to health centers for all socioeconomic groups, especially the very poor and poor.

\section{References}

1. Anna V et Judith T (2011). Les effets économiques de la hausse des dépenses de santé La Vie économique Revue de politique économique.

2. Brigitte D, et Hélène $H$, (2012). Vieillissement de la population et croissance des dépenses de santé. [Rapport de recherche] Université Paris 1 Panthéon-Sorbonne;France. pp.26. Hal-01520109.

3. DREES, (2008). Les comptes nationaux de la santé en 2006 . $\mathrm{N}^{\circ} 655$ - septembre 2008

4. DREES, (2019) Le poids des dépenses de santé dans le revenu des ménages. La complémentaire santé

5. DREES, (2019). Les dépenses de santé en 2018 - Résultats des comptes de la santé - Édition 2019

6. GWATKIN D.R et al. (2007). Socioeconomic differences in Health, Nutrition and Population within developing countries - An overview. Washington DC, the World Bank.

7. Harouna T, (2012). Approche géographique du paludisme dans la commune de MBORA Mémoire de mater 2. Faculté des lettres et sciences humaines. Département de géographie.104 pages. Université Cheick Anta Diop de Dakar.

8. HBS, (2014). Statistics Belgium http://statbel.fgov.be

9. INS., (2011). Enquête Nationale sur les Dépenses de Consommation et le Niveau de Vie des Ménages. Dépenses de santé et d'hygiène corporelle. $\mathrm{N}^{\circ} 716$

10. Jean-Claude B et Juliette S., (2009). Dépenses de santé et équité dans l'accès aux services de santé dans les pays en développement de Boeck Supérieur| Revue d'économie du développement . 2009/1 Vol. 17 | pages 33 à 71 ISSN 12454060 ISBN 2804102586. Article disponible en ligne à l'adresse : https://www.cairn.info/revue-d-economie-dudeveloppement-2009-1-page-33.htm 
11. Jos S., (1997). Revenus disponibles et dépenses des ménages crisp | Courrier hebdomadaire du CRISP 1997/29 n 1574 1575 | pages 1 à 65 ISSN 0008-9664 Article disponible en ligne à l'adresse : https://www.cairn.info/revue-courrierhebdomadaire-du-crisp-1997-29-page-1.htm .Comité régional de la Méditerranée orientale Septembre 2004. Http://www.who.int/countries/ner/fr

12. JULIA C, et al., (2019). Les dépenses de santé en 2018. Résultats des comptes de la santé. Ministère de l'économie, des finances et du plan direction générale de la planification et des politiques économiques en partenariat avec UNICEF. Édition 2019

13. Ke X, (2005). La distribution des paiements de santé et des dépenses catastrophiques : la méthodologie. EIP/HSF/DP.05.2 -. Enquête sur le budget des ménages. Département de financement de santé Organisation mondiale de la santé, Genève

14. Myriam M, Raphael T, et Alexis M, (2017). Les dépenses de santé en 2016 Résultats des comptes de la santé É D I T I O $\mathrm{N} 2017$

15. Nicolas C, et al., (2001). Les dépenses de santé à la charge des ménages. La complémentaire santé. Édition 2019 DREES

16. Nicolas C, Vincent T, et Bruno V, (2001). Politiques de santé dans un modèle macroéconomique : un exercice de simulation. Département des études de l'OFCE . Revue de l'OFCE 78

17. OCDE (2017), « Dépenses de santé en proportion du PIB », dans Health at a Glance 2017 : OCDE Indicators, Paris. DOI: https://doi.org/10.1787/health_glance-2017-45-fr

18. OMS, (2009). Les fiches présentant les Stratégies de coopération avec les pays ne sont pas une publication officielle de l'OMS. This brief is available online at http://www.who.int/countryfocus .WHO/DGR/CCO/09.03/Niger
19. OMS, (2018), Genève, base de données de l'OMS sur les dépenses de santé mondiales. Statistical Yearbook (Sixty-first issue). Annuaire statistique (Soixante et unième édition)

20. Ousmane Faye, (2006). Analyse des dépenses publiques dans les secteurs sociaux au Sénégal sur la période 2006 - 2013 avec accent sur l'éducation et la santé.

21. Pr M. Mrabet. Consommation médicale.Cours

22. République démocratique du Congo., (2018). Améliorer la Dépense de Santé pour Renforcer le Capital Humain et Assurer une Croissance Inclusive. 60 pages

23. Stéphane C., (2018). Un aperçu de la composition des dépenses des ménages Coup d'œil Sociodémographique. Institut de la statistique du Québec. ISSN 1920-9444 (en ligne)

24. SOUMANA B, MAHAMADOU M .A.,( 2015). Analyse des systèmes de production de la riziculture hors aménagement dans les communes rurales de Zabori et Karakara au Niger. Annales de l'Université Abdou Moumouni,Tome XIX-Avol.2, 135-148

25. CRESPO, Stéphane (2018). «Un aperçu de la composition des dépenses des ménages ", Coup d'oeil sociodémographique, [En ligne], no 67, juillet, Institut de la statistique du Québec, p. 1-9. [Www.stat.gouv.qc.ca/statistiques/populationdemographie/bulletins/coupdoeil-no67.pdf].

26. WINTER G. (1967). Méthodologie des enquêtes "Niveau de vie" en milieu rural Africain. Bilan des 3 enquêtes effectuées au Cameroun de 1961 à 1965. 305 pages

27. Mireille E., (2002). 05791 Les déterminants individuels des dépenses de santé. ISSN 1146-9129 - CPPAP 0506 B. www.sante.gouv.fr/htm/publication

28. Didier P., (2007). Manuel de cartographie.extrait de son ouvrage « la carte : moyen d'action » aux éditions ellipses.96 pages 